\title{
The strategy of Regional Medium Term Development Plan policy of Cianjur regency
}

\author{
Denny Aditya Dwiwarman \\ Universitas Putra Indonesia Cianjur \\ Email: dnnaditya@gmail.com
}

(Received: January-2020; Reviewed: February-2020; Accepted: February-2020;

Avalaible Online: March -2020; Published: March-2020)

(c) (3) This is an open access article distributed under the Creative Commons Attribution License
CC-BY-NC-4.0 (C)2020 by author (https://creativecommons.org/licenses/by-nc/4.0/)

\begin{abstract}
The Regional Medium-Term Development Plan (RPJMD) as a mandatory document in the planning process carried out by local governments is one of the vital documents that determines the future development direction of an area. The purpose of this study was to determine the policy evaluation strategy aimed at the Regional Medium Term Development Plan (RPJMD) for the 2011-2016 period, with the locus of Cianjur Regency. The strategy that can be carried out by the Cianjur Regency government refers to the Priority scale pattern which is based on the calculation results of the Analitycal Hierarchy Process (AHP), which essentially follows the pattern; (1) dimension of perception equation, (2) dimension of accuracy, (3) dimension of equalization, (4) dimension of responsiveness. (5) the dimension of adequacy, (6) the dimension of efficiency, (7) the dimension of effectiveness. The results showed that in order to increase people's purchasing power and create a prosperous South Cianjur community, the Regional Government and DPRD of Cianjur Regency are expected to be able to increase synergy, both in the form of coordination and collaboration, especially in relation to the preparation of the Regional Medium-Term Development Plan in the coming period by making road infrastructure development one of the Cianjur Regency Development Missions. This is very important to do, so that road infrastructure development gets serious attention from various stakeholders.
\end{abstract}

Keywords: Policy Evaluation; Strategy; Regional Medium Term Development Plan

\section{INTRODUCTION}

The field of public works is a vital regional government administration affair to encourage and support the functioning of development activities in other fields, particularly the economy and tourism sector. This is understandable considering that the field of public works has links with various fields of development in the 2011-2016 RPJMD (Collier \& Lakoff, 2015).

In line with the above context, Kodoatie argues that: "infrastructure as the main support for the social and economic systems is implemented in a comprehensive and integrated context. 
Infrastructure is a facility developed for government functions in the case that public services cannot function independently and separately". While Grigg and Fontane (2000) explain the types of infrastructure are divided into 7 major groups, namely; 1) Transportation (Roads and Bridges) 2) Transportation services 3) Communication. 4) Water (Drainage, irrigation, rivers, open channels, pipes, etc.) 5) Waste Management 6) Buildings 7) Distribution and Energy Production (Grigg, 2000; Sucipto et al., 2018).

Meanwhile, to increase regional accessibility in the context of tourism development, road infrastructure is needed in a stable condition, this can be seen from the percentage of road infrastructure in steady condition to increase regional accessibility in the context of tourism development in 2015 which decreased by $7.20 \%$ and realized 7.18 . \% or $93.462 \mathrm{KM}$ while the remaining $92.82 \%$ is in moderate and heavily damaged road conditions. Thus, the achievement of road infrastructure performance indicators is in a steady state to improve regional accessibility in the context of tourism development that has not yet met the predetermined performance targets, this is due to the absence of development goals, targets, strategies and policies that focus road infrastructure development towards accessing tourism potentials that are located in South Cianjur, so that it has an impact on people's purchasing power to decline, and the people of South Cianjur are below the poverty line.

Tourism is one of the mainstays of Cianjur Regency's Regional Original Revenue (PAD) and has an important role in the development of Cianjur Regency, given the many tourism potentials in Cianjur Regency. In the 2011-2016 RPJMD, the tourism sector is included in the third mission, namely "increasing people's purchasing power", with the aim of increasing coastal, natural and cultural-based tourism, which is able to compete to meet the needs of tourists, while still adhering to the principle of sustainable development (Hamiyati \& Doriza, 2019; Houge Mackenzie et al., 2020; Husain et al., 2018; Pan et al., 2020; Papalapu et al., 2016; Said et al., 2017).

Based on the description above, it can be seen that the development of the tourism sector, especially South Cianjur tourism, has not been effectively carried out by the local government of Cianjur Regency because there are still many damaged road accesses to potential destinations in South Cianjur beach as a marine tourism object, which has an attraction for local and foreign tourists. , such as Pangandaran and Pelabuhan Ratu.

As a result of the uneven road infrastructure development (trackel down effect), especially those heading to the tourism object area of South Cianjur to be an underdeveloped area in West Java, so that the first impact on the acceleration of the number of poor people in Cianjur Regency in 2014 was 256,600 people or (11, 47\%), sources from the media (www.likethis.com 2014/11/2014) (Siemiatycki, 2011).

The second impact is that the potential of the South Cianjur coastal tourism sector has not been able to compete to meet the needs of tourists such as Pelabuhan Ratu Sukabumi Beach and Pangandaran Beach so that the coastal communities of South Cianjur have not been able to increase income to meet their living standards, the Human Development Index (IPM) of Cianjur Regency has only reached 62, 08 is below the average of West Java Province with an average difference of $2.47 \%$. Life expectancy is still below West Java or has just reached 69 years below Bekasi City, as a result, the potential for Regional Original Income (PAD) from the coastal tourism sector in South Cianjur has not been optimally explored (Fyall \& Garrod, 2005).

\section{METHOD}

The approach used in this research is the Mix Method approach. In essence, mixed methods research is an approach that combines or associates both qualitative and quantitative forms. Mixed methods research is a research method that involves the use of 2 methods, namely qualitative research methods and quantitative methods in a single study or one study. This type 
of research is more complex when compared to other studies, it does not only collect and analyze two types of data, but also involves the functions of qualitative research and quantitative research, so that the overall size is bigger than the two studies. In general, there are four purposes for using mixed research methods, as described by Creswell (2010), which are as follows (Creswell, 2010):

1. To better understand the research issue or problem by triangulating qualitative data in the form of descriptive details with quantitative data in the form of numbers.

2. To obtain quantitative statistical results from a particular sample, then follow up by observing or interviewing a number of individuals in order to obtain a more in-depth explanation of the statistical results that have been obtained.

3. To explore a participant's view (qualitative) for further analysis based on a broad sample (quantitative).

4. To reveal the rights and tendencies of an oppressed group or individuals.

The arguments or reasons for using mixed research methods are seen as providing a more complete understanding of the research issue or problem than the use of one research method. Thus, this study is expected to be able to uncover problems in various perspectives regarding the evaluation of the Cianjur Regency RPJMD policies in 2011-2016 in the field of road development based on South Cianjur Tourism. In addition, the emphasis on the mixed approach (mix method) is based on the consideration that the focus of this research is directed to reveal the process and find meaning in depth and systematically about the evaluation of the Cianjur Regency RPJMD policy in 2011-2016 in the field of road development based on Tourism in South Cianjur, Java Province. West.

\section{RESULT AND DISCUSSION}

In accordance with the context of the problem formulation proposed in the background, this section will explain the results of the analysis of the RPJMD policy evaluation strategy that can be carried out by the Cianjur Regency Government to develop tourism-based road infrastructure development, especially in the South Cianjur region. To analyze this strategy, researchers used the Analitycal Hierarchy Process (AHP). Analitycal Hierarchy Process (AHP) is a method for solving a complex unstructured situation into several components in a hierarchical arrangement, by giving subjective values about the relative importance of each variable, and determining which variables have the highest priority in order to influence the outcome of the situation. The (Chen, 2006; Giampiccoli \& Saayman, 2017; Khadaroo \& Seetanah, 2007; Sumantra \& Yuesti, 2018).

The stages of the Analitycal Hierarchy Process (AHP) can be explained as follows: (1), Problem Decomposition; (2) Assessment / weighting to compare elements, (3) Compilation of matrices and consistency tests, (4) Prioritization of each hierarchy, (5) Synthesis of priorities, and (5) Decision making / determination.

To map the assessment of the dimensions and indicators of the RPJMD policy evaluation, the researcher then translated the operational variables into a questionnaire. As for the alternative answers proposed, as explained below (McCreary \& Thompson, 2006):

Answer the questions below by selecting: If the criteria on the left and on the right are equal.

1. On the left if the criteria on the left are less important (moderate) than the right, and vice versa.

2. On the left if the criteria on the left are more important (strong) than the right, and vice versa.

3. On the left if the criteria on the left are very important (extremely) from the right, and vice versa. 
4. On the left if the criteria on the left are very much more important (extremely) than the right, and vice versa.

The Analitycal Hierarchy Process (AHP) hierarchy chart is as shown in the image below:

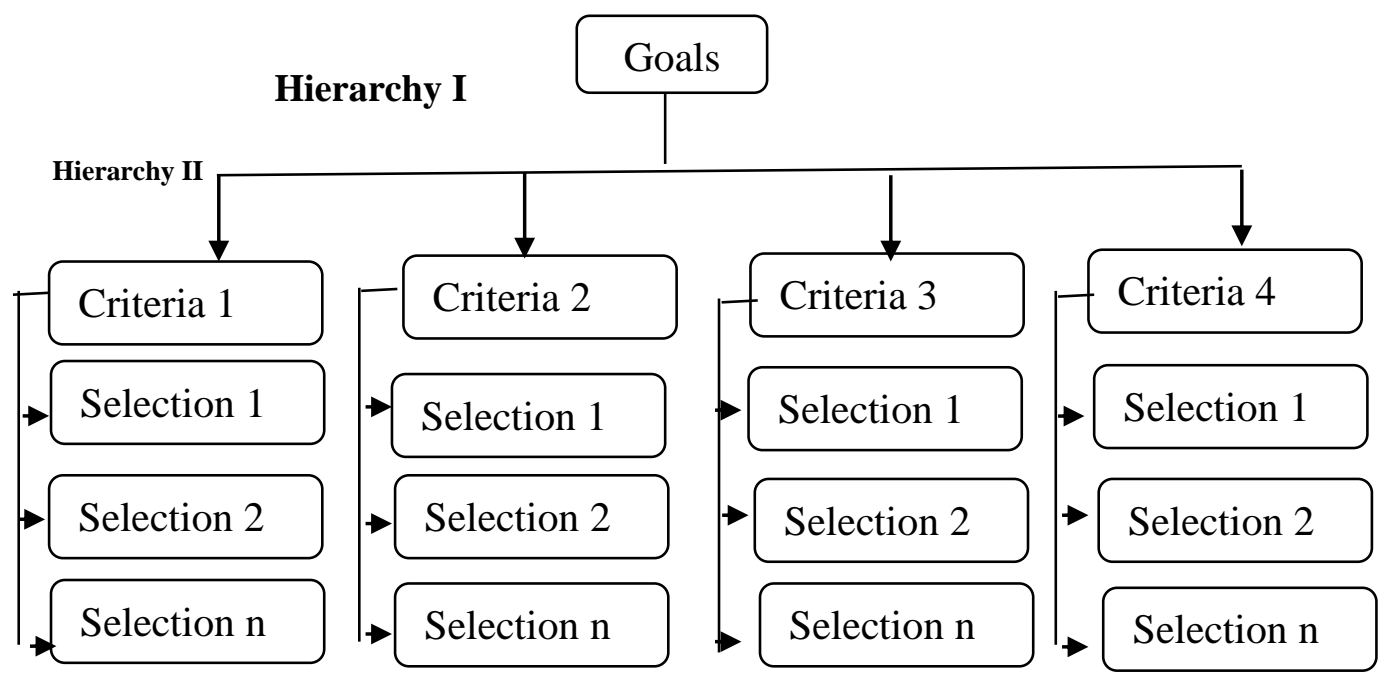

\section{Hierarchy III}

Picture.1 hierarchy AHP

Meanwhile, to assess the priority scale based on predetermined hierarchical criteria, it is given to stakeholders involved in the Cianjur Regency RPJMD process who methodologically act as respondents. The respondents in question, amounted to 78 people.

Understanding the characteristics of respondents in the context of academic research is very important to pay attention to, remembering to maintain the objectivity of the results of the responses given by these respondents. The characteristics of the respondents that will be explained in the context of the Cianjur Regency RPJMD policy evaluation research 2011-2016 are based on the work unit, gender, age, and education level. While the analysis of the characteristics of the respondents in question can be explained below:

Characteristics of Respondents Based on Work Units, can be comprehensively explained in the table below:

\section{Table 1.}

Characteristics of Respondents Based on Work unit

\begin{tabular}{cll}
\hline No & Work Unit / Position & amount \\
\hline 1 & Cianjur Regency DPRD & 21 People \\
2 & the regional Secretariat & 1 People \\
3 & PUPR / Bina Marga Office & 7 People \\
4 & Government tourism office & 9 People \\
5 & Bappeda & 8 People \\
6 & DPKAD Cianjur Regency & 1 People \\
7 & Cianjur Regency DPRD Secretariat & 10 People \\
8 & Academics & 7 People \\
9 & South Cianjur Community Leaders & 14 People \\
\hline & Amount & $\mathbf{7 8 ~ P e o p l e ~}$
\end{tabular}

Source : Cianjur Regency Government, Processed by Researchers in 2018 
As for the characteristics of respondents based on gender, as a whole can be seen in the table below:

Table 2.

Characteristics of Respondents Based on

\begin{tabular}{|c|c|c|c|}
\hline \multicolumn{4}{|c|}{ Gender } \\
\hline No & Gender & Amount & $\begin{array}{c}\text { Percentage } \\
(\%)\end{array}$ \\
\hline 1 & Male & 55 People & 70,5 \\
\hline 2 & Female & 23 People & 29,5 \\
\hline & Jumlah & 78 People & 100 \\
\hline
\end{tabular}

Source : Cianjur Regency Government, Processed by Researchers in 2018

While the characteristics of respondents based on age or age, as a whole can be seen in the table below:

\section{Table 3.}

Characteristics of Respondents Based on

\begin{tabular}{llcl}
\hline No & Gender & Amount & Percentage \\
\hline 1 & Under 25 Years & - & - \\
2 & $25-36$ Years & 14 People & $18 \%$ \\
3 & $36-45$ Years & 28 People & $36 \%$ \\
4 & Above 45 Years & 36 People & $46 \%$ \\
\hline Amount & & $\mathbf{7 8 ~ P e o p l e ~}$ & $\mathbf{1 0 0 \%}$ \\
\hline
\end{tabular}

Source : Cianjur Regency Government, Processed by Researchers in 2018

Then the characteristics of respondents based on education, as a whole can be seen in the table below:

Table 4.

Characteristics of Respondents Based on Education

\begin{tabular}{clcc}
\hline No & Gender & Amount & Percentage (\%) \\
\hline 1 & Junior High School & 2 People & 2,5 \\
2 & Senior High School & 11 People & 14 \\
3 & Bachelor & 43 People & 55 \\
4 & Master & 22 People & 28,5 \\
\hline & Amount & $\mathbf{7 8 ~ P e o p l e ~}$ & $\mathbf{1 0 0}$
\end{tabular}

\section{Source : Cianjur Regency Government, Processed by Researchers in 2018}

Based on the results of the Analitycal Hierarchy Process, this section will discuss which dimensions and indicators show the priority scale in determining the RPJMD policy evaluation. In other words, the results of this analysis will provide a comprehensive picture of what steps or strategies the Cianjur Regency Government needs to take in evaluating RPJMD policies. Through these steps or strategies, the Cianjur Regency Government is expected to be able to improve the grand design of the RPJMD in the future. The results of the calculation of the 
Analytical Hierarchy Process (AHP), the evaluation of the RPJMD can be seen in the table below (Arts et al., 2013; Bouten et al., 2011):

Table 5.

Calculation Results of the Analitycal Hierarchy Process (AHP)

\begin{tabular}{ll}
\hline Level 1 & Level 2 \\
\hline Perception Equation $=. \mathbf{3 3 5}$ & Goal $=.093$ \\
& Target $=.087$ \\
& Realization $=.076$ \\
& Target $=.042$ \\
\hline \multirow{2}{*}{ Accuracy $=\mathbf{. 1 5 9}$} & Performance Indicator $=.037$ \\
& Policy Accuracy $=.056$ \\
& Accuracy of Budget Management $=.048$ \\
& Coordination Accuracy $=.035$ \\
& Punctuality $=.020$ \\
\hline Equity $=. \mathbf{1 3 1}$ & Target Accuracy $=.090$ \\
& Program coverage $=.041$ \\
\hline Responsiveness $=\mathbf{. 1 3 0}$ & Speed of Responding to Complaints $=.065$ \\
& Open Receiving Input $=.036$ \\
& Sensitive to Criticism $=.029$ \\
\hline Adequacy $=\mathbf{. 1 1 4}$ & Human Resources $=.052$ \\
& Budget $=.032$ \\
& Facilities $=.017$ \\
& Technology $=.013$ \\
\hline Efficiency $=\mathbf{. 0 7 6}$ & Budget Usage $=.030$ \\
& Use of Human Resources $=.024$ \\
& Facility Use $=.013$ \\
& Technology Usage $=.009$ \\
\hline Effectiveness $=. \mathbf{0 5 5}$ & Achievement of Objectives $=.026$ \\
& Contribution to Objectives $=.018$ \\
& Comparison of expected results $=.011$ \\
\hline
\end{tabular}

\section{Source: Data Processing Results, 2018}

Based on the results of the above calculations, the priority scale that must be considered when determining the RPJMD policy evaluation is the perception equation dimension with a priority value of 0.335 , followed by the accuracy dimension with a priority value of 0.159 . This is followed by the dimension of equalization with a priority value of 0.131 , followed by the dimension of responsiveness with a priority value of 0.130 , while the adequacy dimension gets a priority value of 0.114 , then the efficiency dimension is 0.076 , while the last dimension affecting the determination of the RPJMD policy evaluation is the effectiveness dimension. which is 0.055 .

To explain comprehensively the results of the Analytical Hierarchy Process (AHP) in the context of the Cianjur Regency RPJMD policy evaluation 2011-2016, it can be seen in the description below

\section{Analysis of Policy Evaluation Strategies Based On Dimensions}

As explained above, that the RPJMD policy evaluation strategy is based on the priority scale of the policy evaluation dimension, the following pattern is obtained; first, the dimension of the perception equation with a priority value of 0.335 . Second, the dimension of accuracy 
with a priority value of 0.159 . Third, the dimension of equalization with a priority value of 0.131 . Fourth, the dimension of responsiveness with a priority value of 0.130 . Fifth, the adequacy dimension gets a priority value of 0.114. Sixth, the efficiency dimension is 0.076 . Seventh, the dimension of effectiveness, which is 0.055 .

Based on the results of the Analytical Hierarchy Process (AHP), the pattern of the Cianjur Regency RPJMD policy evaluation strategy for 2011-2016, based on the dimensions of policy evaluation, can be described in the image below:

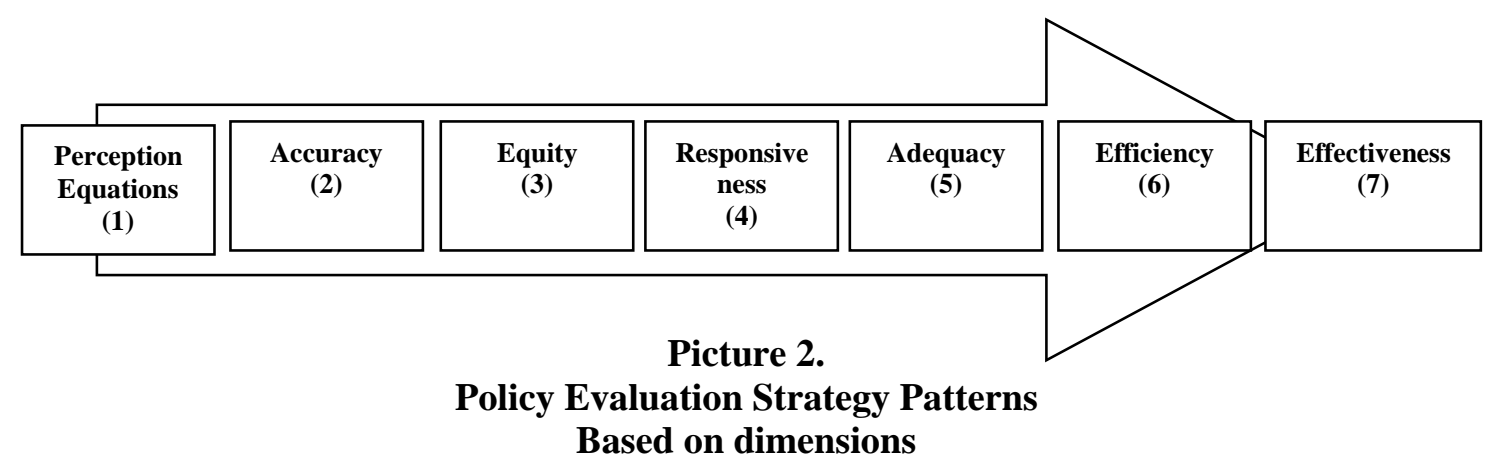

Based on the picture above, the researcher can provide an interpretation that to optimize the evaluation of the Cianjur Regency RPJMD policy, the Cianjur Regency Government needs to take strategic steps by referring to the RPJMD policy evaluation strategy pattern as described above. In this context, the strategic steps that must be implemented by the Cianjur Regency Government to evaluate the Cianjur Regency RPJMD policies for 2011-2016 should prioritize the following steps; the first is the perception equation dimension, the second is the accuracy dimension, the third is equalization dimension, the responsiveness is the fourth dimension, the sufficiency dimension is the sixth dimension of efficiency and the seventh dimension of effectiveness.

\section{Analysis of Policy Evaluation Strategy Based on Indicators}

In addition to the analysis based on dimensions, the Analytical Hierarchy Process (AHP) also explains the strategy for evaluating the Cianjur Regency RPJMD policy based on the indicators of each dimension. As for a comprehensive explanation of the priority scale pattern of each indicator, it can be explained as follows:

\section{Dimensions of the Equation Of Perception}

The similarity in perceptions among all stakeholders in the context of the Cianjur Regency RPJMD policy evaluation 2011-2016, is a very important dimension to pay attention to, it is even a top priority in supporting the success of the policy evaluation. Empirically, the success of the perception equation dimension in supporting the implementation of policy evaluation is determined by five indicators, namely; Equation indicators of perceptions about objectives, targets, performance indicators, realization and target indicators (Mangi \& Austen, 2008; Van Kleef et al., 2006)

Based on the results of the calculation of the Analytical Hierarchy Process (AHP), the Cianjur Regency RPJMD policy evaluation strategy pattern for 2011-2016 is obtained based on the indicators of the perception equation dimensions as shown in the figure below: 


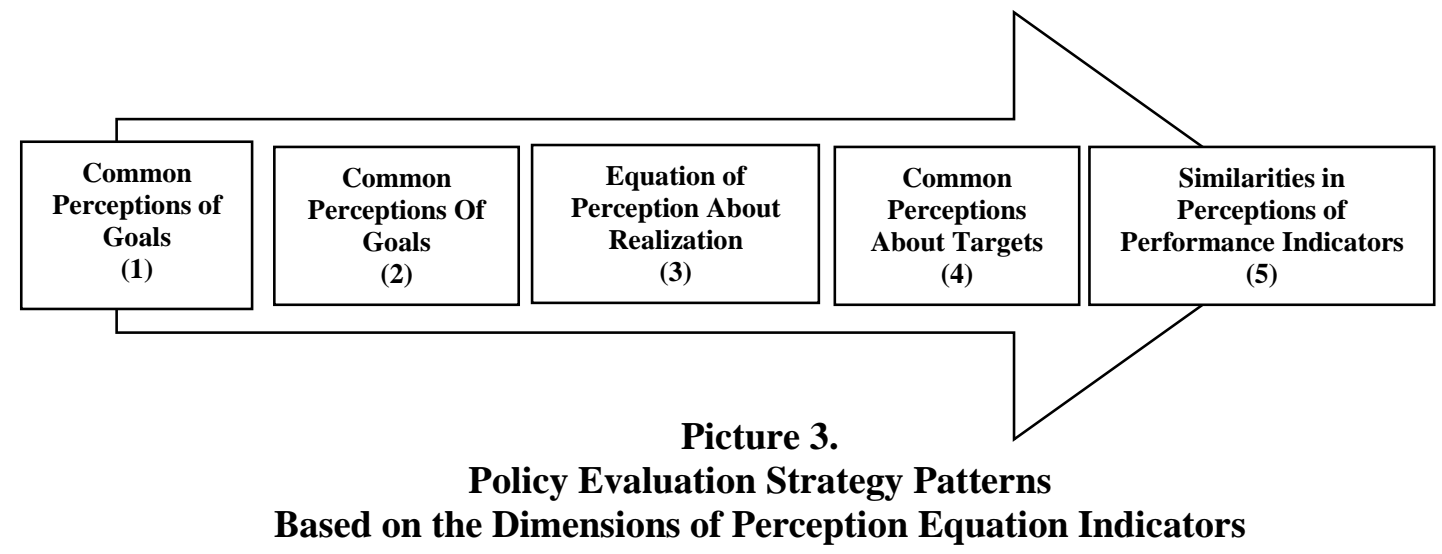

Based on the picture above, the researcher can provide an interpretation that in order to optimize the evaluation of the Cianjur Regency RPJMD policy based on the indicators of the dimension of perception equality, the Cianjur Regency Government needs to take strategic steps by referring to the RPJMD policy evaluation strategy pattern as described above. In this context, the strategic steps that must be implemented by the Cianjur Regency Government to evaluate the Cianjur Regency RPJMD policies for 2011-2016 include prioritizing, among others:; first, the equality of perceptions indicator about objectives, the second, the equality of perception indicators about targets, the third is the perception equation of realization, the fourth is the perception equation indicator about the target, and the fifth is the perception equation about performance indicators (Herlina \& Suryana, 2020).

\section{Dimensions of accuracy}

The dimension of accuracy is the second priority after the implementation of the dimension of equality of perception in the context of the evaluation of the Cianjur Regency RPJMD policies for 2011-2016. This reflects that the dimension of accuracy occupies a fairly strategic position in supporting the successful evaluation of RPJMD policies. Empirically, the dimensions of accuracy are determined by four indicators, namely: indicators of policy accuracy, accuracy of budget management, accuracy of coordination among stakeholders, timeliness of program completion.

Based on the results of the calculation of the Analytical Hierarchy Process (AHP), the Cianjur Regency RPJMD policy evaluation strategy pattern for 2011-2016 was obtained based on indicators of the accuracy dimension as shown in the figure below:

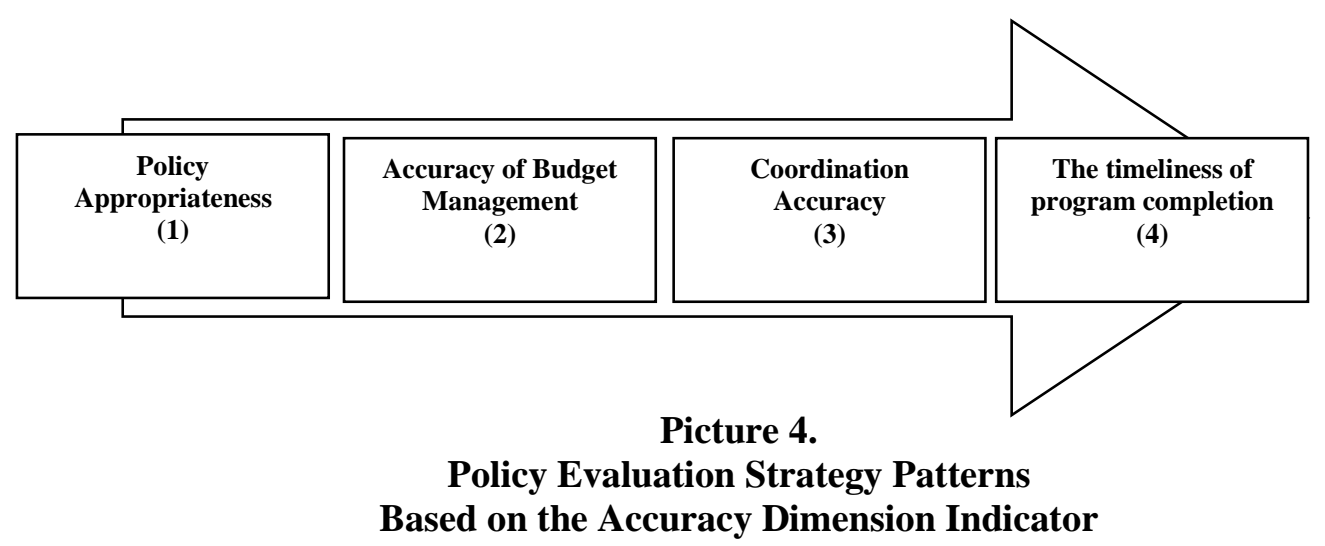


Based on the picture above, the researcher can provide an interpretation that in order to optimize the evaluation of the Cianjur Regency RPJMD policy based on the dimension of accuracy indicators, the Cianjur Regency Government needs to take strategic steps by referring to the RPJMD policy evaluation strategy pattern as described above. In this context, the strategic steps that must be implemented by the Cianjur Regency Government to evaluate the Cianjur Regency RPJMD policies for 2011-2016 include prioritizing, among others:; first, policy accuracy indicator, second budget management accuracy, third coordination accuracy, and fourth indicator timeliness of program completion.

\section{Dimensions of equity}

The dimension of equity is the third priority after the implementation of the dimension of equality of perceptions and the dimension of accuracy in the context of the Cianjur Regency RPJMD policy evaluation 2011-2016. Empirically, the dimension of equity is determined by two indicators, namely: indicators of target accuracy and program coverage.

Based on the results of the calculation of the Analytical Hierarchy Process (AHP), the Cianjur Regency RPJMD policy evaluation strategy pattern for 2011-2016 is obtained based on indicators of the equalization dimension as shown in the figure below:

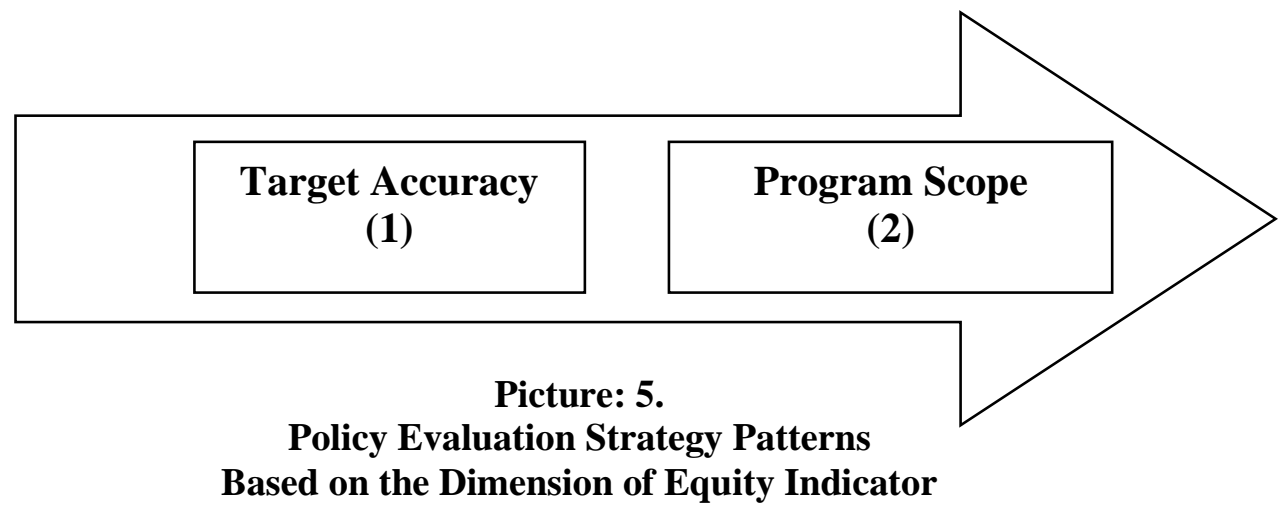

Based on the picture above, the researcher can provide an interpretation that in order to optimize the evaluation of the Cianjur Regency RPJMD Policy based on the indicators of the equity dimension, the Cianjur Regency Government needs to take strategic steps by referring to the RPJMD policy evaluation strategy pattern as describe above. In this context, the strategic steps that must be implemented by the Cianjur Regency Government to evaluate the Cianjur Regency RPJMD policies for 2011-2016 include prioritizing, among others; the first is the target accuracy indicator and the second is the program coverage indicator.

\section{Dimension of Responsiveness}

The dimension of responsiveness is the fourth priority after the implementation of the dimensions of equality of perceptions, dimensions of accuracy, and dimensions of equity in the context of the evaluation of the Cianjur Regency RPJMD policies in 2011-2016. Empirically, the dimension of responsiveness is determined by three indicators, namely: the speed indicator for responding to complaints, being open to receiving input and the indicator being sensitive to criticism.

Based on the results of the calculation of the Analytical Hierarchy Process (AHP), the Cianjur Regency RPJMD policy evaluation strategy pattern for 2011-2016 was obtained based on the indicators of the responsiveness dimension as shown in the figure below: 


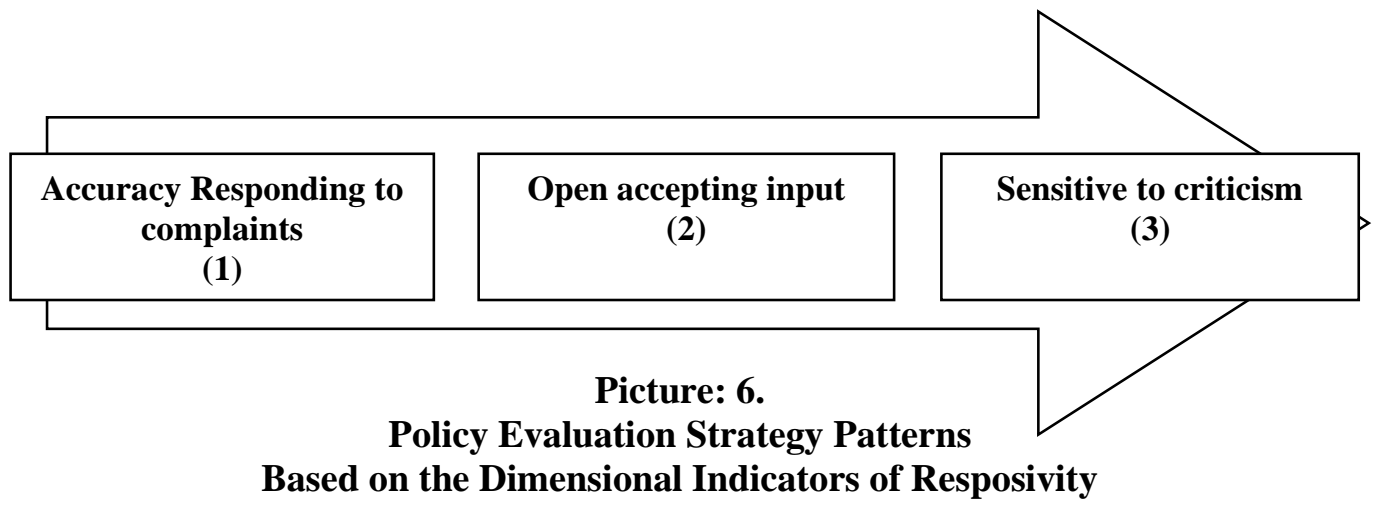

Based on the picture above, the researcher can provide an interpretation that in order to optimize the evaluation of the Cianjur Regency RPJMD policy based on the responsiveness dimension indicator, the Cianjur Regency Government needs to take strategic steps by referring to the RPJMD policy evaluation strategy pattern as described above. In this context, the strategic steps that must be implemented by the Cianjur Regency Government to evaluate the Cianjur Regency RPJMD policies for 2011-2016 include prioritizing, among others:; first, the speed indicator for responding to complaints, the second being open to receiving input and the third, the indicator is sensitive to criticism.

\section{Dimensions of Adequacy}

The dimension of sufficiency is the fifth priority after the implementation of the dimensions of equality of perceptions, dimensions of accuracy, dimensions of equity, and dimensions of responsiveness in the context of the Cianjur Regency RPJMD policy evaluation 2011-2016. Empirically, the adequacy dimension is determined by four indicators, namely: the adequacy of human resources indicators, the adequacy of the budget, the adequacy of facilities and the indicators of the adequacy of technology.

Based on the calculation of Process Hierarchy Analysis (AHP), the Cianjur Regency RPJMD policy evaluation strategy pattern for 2011-2016 is obtained based on indicators of the adequacy dimension as shown in the figure below:

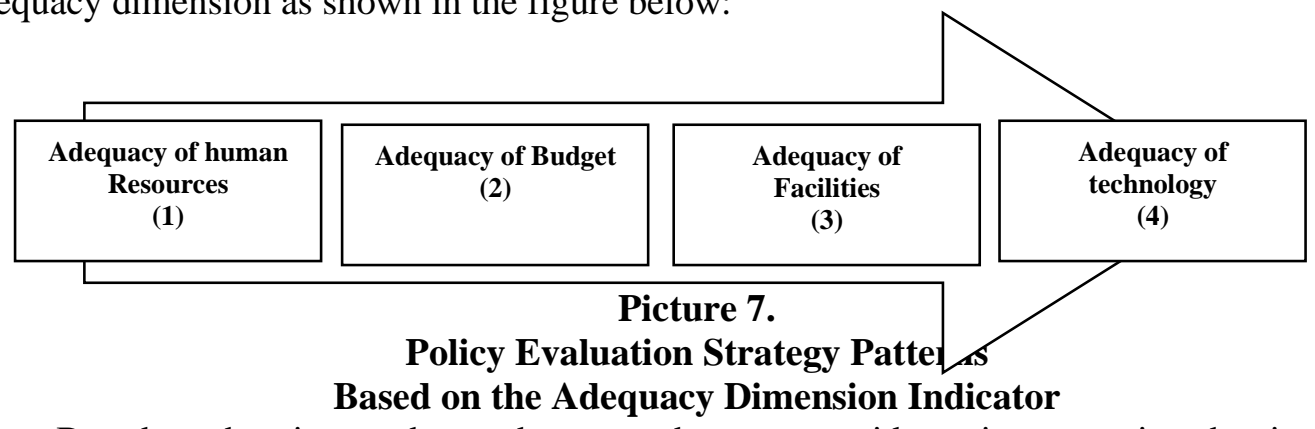

Based on the picture above, the researcher can provide an interpretation that in order to optimize the evaluation of the Cianjur Regency RPJMD policy based on the adequacy dimension indicator, the Cianjur Regency Government needs to take strategic steps by referring to the RPJMD policy evaluation strategy pattern as described above. In this context, the strategic steps that must be implemented by the Cianjur Regency Government to evaluate the Cianjur Regency RPJMD policies for 2011-2016 include prioritizing, among others:; first, human resource adequacy indicator, second, budget adequacy indicator, third, facility adequacy indicator and, fourth, technology adequacy indicator. 


\section{Dimensions of Efficiency}

The efficiency dimension is the sixth priority after the implementation of the dimensions of perception equality, the dimension of accuracy, the dimension of equity, the dimension of responsiveness and the dimension of adequacy in the context of the Cianjur Regency RPJMD policy evaluation 2011-2016. Empirically, the efficiency dimension is determined by four indicators, namely: indicators of efficiency of budget use, indicators of efficiency of use of human resources, indicators of efficiency of use of facilities and indicators of efficiency of use of technology.

Based on the calculation of the Process Hierarchy Analysis (AHP), the Cianjur Regency RPJMD policy evaluation strategy pattern for 2011-2016 is obtained based on indicators of the efficiency dimension as shown in the figure below:

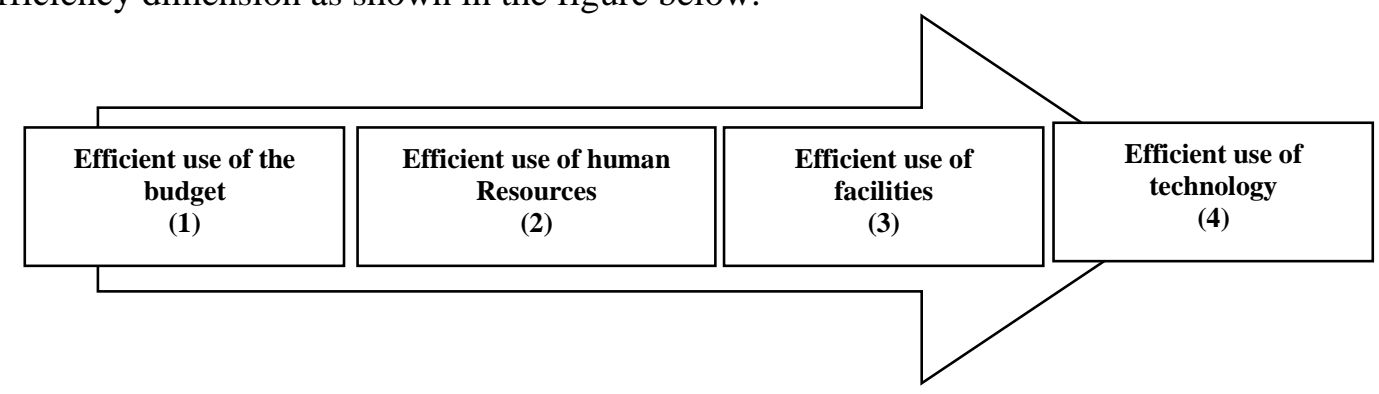

\section{Picture 8. \\ Policy Evaluation Strategy Patterns \\ Based on the Efficiency Dimension Indicator}

Based on the picture above, the researcher can provide an interpretation that in order to optimize the evaluation of the Cianjur Regency RPJMD policy based on the efficiency dimension indicator, the Cianjur Regency Government needs to take strategic steps by referring to the RPJMD policy evaluation strategy pattern as described above. In this context, the strategic steps that must be carried out by the Cianjur Regency Government to evaluate the Cianjur Regency RPJMD policies for 2011-2016, among others prioritize, among others: first indicators of budget use efficiency, second, indicators of efficiency in the use of human resources, third efficiency indicators of the use of facilities, fourth, indicators of efficiency of technology use.

\section{Dimensions of Effectiveness}

The dimension of effectiveness is the last or seventh priority after the implementation of the dimensions of equality of perceptions, dimensions of accuracy, dimensions of equity, dimensions of responsiveness, dimensions of adequacy and dimensions of efficiency in the context of policy evaluation of the Cianjur Regency RPJMD 2011-2016. Empirically, the dimension of effectiveness is determined by three indicators, namely: indicators of goal achievement, contribution to goals and indicators of comparison of expected results.

Based on the calculation of the Process Hierarchy Analysis (AHP), the Cianjur Regency RPJMD policy evaluation strategy pattern for 2011-2016 is obtained based on the indicators of the effectiveness dimension as shown in the figure below: 


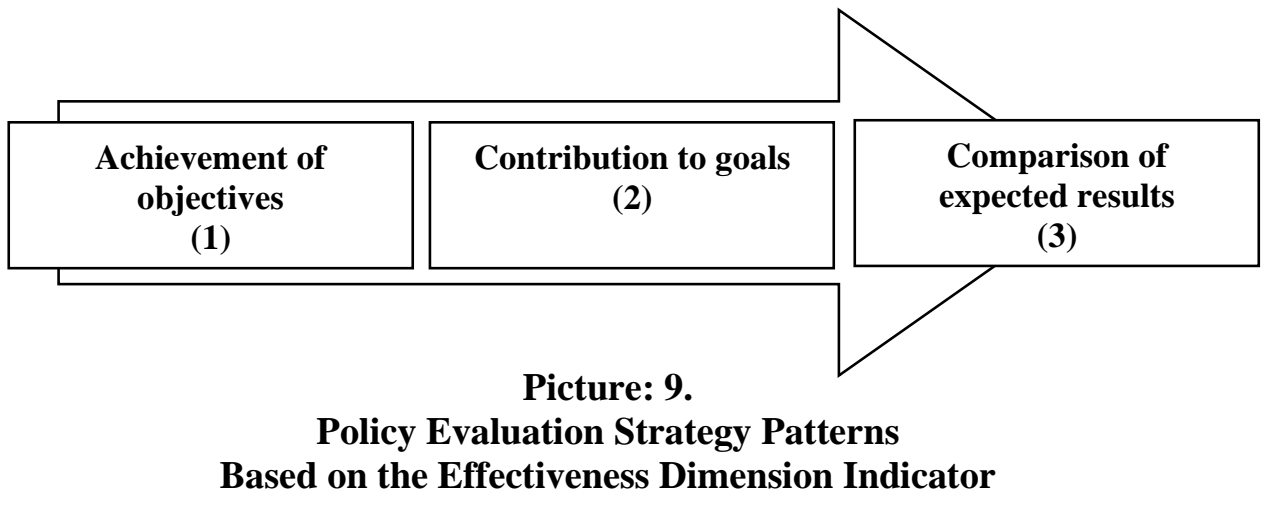

Based on the picture above, the researcher can provide an interpretation that in order to optimize the evaluation of the Cianjur Regency RPJMD policy based on the indicators of the effectiveness dimension, the Cianjur Regency Government needs to take strategic steps by referring to the RPJMD policy evaluation strategy pattern as described above. In this context, the strategic steps that must be implemented by the Cianjur Regency Government to evaluate the Cianjur Regency RPJMD policies for 2011-2016 include prioritizing, among others:; first, indicators of goal achievement, second, indicators of contribution to goals, three indicators of comparison of expected results.

\section{CONCLUSION}

The RPJMD policy evaluation strategy is based on the priority scale of the policy evaluation dimension, with the following strategy patterns; first, the dimension of the perception equation. Second, the dimension of accuracy. Third, the dimension of equity. Fourth, the dimension of responsiveness. Fifth, the dimension of sufficiency. Sixth, the dimension of efficiency. Seventh, the effectiveness dimension, the RPJMD policy evaluation strategy which is based on the priority scale of indicators for each policy evaluation dimension, with the following strategy patterns:

1. Dimensions of the Equation of Perception, with a strategy that prioritizes patterns; first, the equality of perception indicator about objectives, secondly, the equality of perception indicator about the target, the third is the perception equation regarding realization, the fourth is the perception equation indicator about the target, and the fifth is the perception equation about the performance indicator.

2. Accuracy Dimensions, with a strategy that prioritizes the pattern: firstly an indicator of policy accuracy, secondly of accuracy of budget management, third of accuracy of coordination, and of four indicators of timeliness of program completion.

3. Equity Dimension, with a strategy that prioritizes the pattern: first, indicators of target accuracy and second, indicators of program coverage.

4. Responsiveness dimension, with a strategy that prioritizes the pattern: first, the speed indicator for responding to complaints, the second being open to receiving input and the third indicator is sensitive to criticism.

5. Adequacy dimension, with a strategy that prioritizes the pattern: first, the adequacy of human resources, second, the adequacy of budget, third, the adequacy of facilities, and the fourth is the indicator of the adequacy of technology.

6. Efficiency Dimensions, with a strategy that prioritizes the pattern: first, indicators of efficiency in the use of budgets, second, indicators of efficiency in the use of human 
resources, three indicators of efficiency in the use of facilities, fourth, indicators of efficiency in the use of technology.

7. Effectiveness dimension, with a strategy that prioritizes the pattern: first, indicators of achieving goals, second, indicators of contribution to goals, three indicators of comparison of expected results.

\section{REFERENCES}

Arts, S., Appio, F. P., \& Van Looy, B. (2013). Inventions shaping technological trajectories: do existing patent indicators provide a comprehensive picture? Scientometrics, 97(2), 397419.

Bouten, L., Everaert, P., Van Liedekerke, L., De Moor, L., \& Christiaens, J. (2011). Corporate social responsibility reporting: A comprehensive picture? Accounting Forum, 35(3), 187204.

Chen, C.-F. (2006). Applying the analytical hierarchy process (AHP) approach to convention site selection. Journal of Travel Research, 45(2), 167-174.

Collier, S. J., \& Lakoff, A. (2015). Vital systems security: Reflexive biopolitics and the government of emergency. Theory, Culture \& Society, 32(2), 19-51.

Creswell, J. W. (2010). Mapping the developing landscape of mixed methods research. SAGE handbook of mixed methods in social \& behavioral research, 2, 45-68.

Fyall, A., \& Garrod, B. (2005). From competition to collaboration in the tourism industry. Global tourism, 4, 54-72.

Giampiccoli, A., \& Saayman, M. (2017). Community-based tourism, responsible tourism, and infrastructure development and poverty. African Journal of Hospitality, Tourism and Leisure, 6(2), 1-28.

Grigg, N. (2000). Dan Fontane. DG.

Hamiyati, H., \& Doriza, S. (2019). The Impact of the Policy of Karawang City Government in Tourism Development to Support Family Economics in Segaran Village. KnE Social Sciences, 202-207.

Herlina, L., \& Suryana, A. (2020). Implementation Efforts of Regional Autonomy Policy in Education (Analysis of strategic plans of district/city education offices in Indonesia 20132018). 3rd International Conference on Research of Educational Administration and Management (ICREAM 2019), 404-408.

Houge Mackenzie, S., Boudreau, P., \& Raymond, E. (2020). Women's adventure tour guiding experiences: Implications for well-being. Journal of Hospitality and Tourism Management, 45, 410-418. https://doi.org/https://doi.org/10.1016/j.jhtm.2020.09.006

Husain, T., Akib, H., Gani, H. A., \& Guntur, M. (2018). Collaboration of actor in formulation of development program tourism destination in West Halmahera Regency. (Study In Tuada and Bobanehena Village, Jailolo District) - Indonesia. Espacios, 39(44).

Khadaroo, J., \& Seetanah, B. (2007). Transport infrastructure and tourism development. Annals of tourism research, 34(4), 1021-1032.

Mangi, S. C., \& Austen, M. C. (2008). Perceptions of stakeholders towards objectives and zoning of marine-protected areas in southern Europe. Journal for Nature Conservation, 16(4), 271-280. 
McCreary, D. R., \& Thompson, M. M. (2006). Development of two reliable and valid measures of stressors in policing: The operational and organizational police stress questionnaires. International Journal of Stress Management, 13(4), 494.

Pan, Y., Fu, X., \& Youcheng Wang. (2020). How does travel link to life satisfaction for senior tourists? Journal of Hospitality and Tourism Management, 45, 234-244. https://doi.org/https://doi.org/10.1016/j.jhtm.2020.07.013

Papalapu, D. M., Nawawi, J., Tahir, H., \& Akib, H. (2016). The role of the department of social in empowering the street children in Makassar. International Journal of Economic Research, 13(1).

Said, F., Salam, R., Akib, H., \& Baharuddin, A. (2017). An Analysis of Tourism Visit Trend. 149(Icest), 34-36.

Siemiatycki, M. (2011). Urban transportation public-private partnerships: drivers of uneven development? Environment and planning A, 43(7), 1707-1722.

Sucipto, M., Raharjo, T. J., Martono, S., Sugiharto, D. Y. P., \& Virgiawan, A. K. (2018). The Implementation of Management Information System of Planning School Infrastructure Development Based on Priority Scale (SIMPPIS) to Improve Students' Achievement. International Conference on Science and Education and Technology 2018 (ISET 2018).

Sumantra, I. K., \& Yuesti, A. (2018). Evaluation of Salak Sibetan Agrotourism to Support Community-Based Tourism Using Logic Model. International Journal of Contemporary Research and Review, 9(01).

Van Kleef, E., Frewer, L. J., Chryssochoidis, G. M., Houghton, J. R., Korzen-Bohr, S., Krystallis, T., Lassen, J., Pfenning, U., \& Rowe, G. (2006). Perceptions of food risk management among key stakeholders: Results from a cross-European study. Appetite, 47(1), 46-63. 